\title{
Skill and General Characteristics of Bangladeshi Migrant Workers: A Study on Manikgonj District
}

\author{
Idris Ali, Muhammad Helal Uddin, Md. Kamrujjaman \\ Department of Business Administration, Manarat International University, Gulshan, Dhaka, Bangladesh \\ Email address \\ idris_ukf@yahoo.com (I. Ali), helaluddin.du@yahoo.com (M. H. Uddin), jeweldu@yahoo.com (M. Kamrujjaman)
}

To cite this article:

Idris Ali, Muhammad Helal Uddin, Md. Kamrujjaman. Skill and General Characteristics of Bangladeshi Migrant Workers: A Study on Manikgonj District. Journal of World Economic Research. Vol. 4, No. 2, 2015, pp. 32-37. doi: 10.11648/j.jwer.20150402.12

\begin{abstract}
This paper presents the skill and general characteristics of Bangladeshi migrant workers who are working in different parts of the world and currently contributing to the national economy of Bangladesh through sending robust remittance. The study obtained the opinions of 100 Bangladeshi migrant workers from Manikgonj district in Bangladesh through a survey to find the skill and general characteristics of Bangladeshi migrant workers. To conduct this study, qualitative (expert interview, focus group discussion) and quantitative methods was used. The study is based on primary data collection through questionnaires and Statistical Package for Social Science (SPSS) was used to analyze the data. The study found that most of the workers from Bangladesh are unskilled to semi-skilled, which keeps them in the lowest paying job. Despite this they are sending a high level of remittances. They are able to do so because they are sacrificing decent living conditions, health care, nutrition, education, and training. Finally, this study came up with some recommendations to enhance the skill of the Bangladeshi migrant workers so that they can be benefitted personally themselves and contribute much more to the economy of the country through sending more remittance. Nevertheless, the results of the study are constrained by the size of the sample, area and robustness of the analysis.
\end{abstract}

Keywords: Skill, Migrant Worker, General Characteristics, Remittance, Bangladesh

\section{Introduction}

There are around 8 million skilled and unskilled Bangladeshi migrants working in more than 108 countries starting from Middle East to the Far East and also Europe to North America. Wage earners contribute almost $15 \%$ in our gross domestic product (GDP) through sending hard earned remittance to Bangladesh. But the progression in this booming foreign currency-earning sector has been following a regressional course than a progressional one due to several reasons. The migration cost in Bangladesh is very high compared with that of other labor sending countries of South Asia. Skill and is an inseparable quality of migrant worker as earnings of them largely depends on their skill. Earnings of skilled workers are greater than unskilled workers in all over the world. That's why skill of migrant workers is very much crucial. Further, the efficiency-wage hypothesis holds for the low-wage, unskilled workers in the informal sector since at very low wage rates, such as those that exist for the unskilled workers in the informal sector, mere needs of minimal nutrition, and, sometimes transportation costs, provide grounds for modeling the unskilled, informal structure in this manner. However, skill is the learned ability to carry out a task with pre-determined results often within a given amount of time, energy, or both. In other words the abilities that one possesses. Skills can often be divided into domain-general and domain-specific skills. For example, in the domain of work, some general skills would include time management, teamwork and leadership, self-motivation and others, whereas domain-specific skills would be useful only for a certain job. Skill usually requires certain environmental stimuli and situations to assess the level of skill being shown and used. But matter of regret is that skills of Bangladeshi migrant workers are not in the satisfactory level. Due to poor skill, earnings are very poor of Bangladeshi migrant workers in comparison with average income of other countries migrant worker.

\section{Literature Review}

"The migration of workers across international boundaries in search of economic opportunity has enormous implications for development. It can have significant positive impacts on 
household poverty and economic growth through improved income opportunities, knowledge transfers and increased integration in the global economy." (World Bank 2006). Vadean, P. and Florin, (2006) in his paper aimed to provide insight into the way in which the education and skill level of migrants affects the remittances habit, purpose and use, in the context of Afghan, Egyptian and Serbian immigrants groups in Germany. The information about the remittances patterns of the immigrant groups, identified by a snowball sampling technique. In this paper conclude that whether skilled migrants remit more or less compared to low skilled ones is not straightforward, this study provides evidence that the skill level significantly affects the purpose of remittances towards more productive investment. Whilst low skilled migrants mainly remit for securing the consumption need of their family members, the remittances of middle skilled migrants are more often used for investment saving(e.g. buying of real estate or bank account deposits), and high skilled migrants make also Productive investments in their home countries.

Koettl, J. (2006) explains about the cost and benefit of skilled and unskilled labour migration. Brain drain is a major concern to source countries for a number of reasons. Through highly skilled migration, source countries lose a significant amount of human capital. Empirical evidence shows that the highly skilled migration might also be less prone to send remittances back home. Highly skilled migrants typically earn more- and thus, ceteris paribus, they should remit more than low skilled migrants. Quartey Peter (2006) concludes that migration of both skilled and unskilled labour has been one of the survival strategies of many African countries particularly the youth. Similarly, migrating from Ghana to Europe and America has become one of the surest means of acquiring skills and also improving the living standards of both the skilled and unskilled labour force. In IOM (2008) includes that highly skilled migrants are involved in various migration scenarios. The largest stock of skilled migrant workers consists of permanent residents, even though the flow of short- term migrants is increasing and often exceeds the yearly admission of skilled immigrants on a permanent basis. Mulina, T. and others (2006) conclude that migration and remittances are significant component of Samoa and Tonga. It's providing income support for a large section of population and thus improving living standards and alleviating poverty at the household level. Here also conclude that the higher propensity for skilled migrants entering Australia to remit more money home than is the case among unskilled migrants to New Zealand. In this study used interview of 471 households in the two countries. Here used descriptive model and the Probit Model to analysis the data.

Mahmood, R. A. (1992) observes that the maximum levels of gains from migration are achieved by professionals and semi-professionals. He also includes that the professional and semi-professional migrants have the highest relative share of those who managed to start some trade or business out of remittances. Among the different categories of migrants, the incidence of post- migration unemployment is the highest for unskilled migrants: 57 percent, compared to a pre-migration level of 15 percent. The next most affected group is the skilled migrants: unemployment among them increased from 14 to 47 percent. The various aspects of the changes in income after migration are closely related to the skill level of the returned migrants and the length of their stay abroad. The unskilled migrants experienced the most significant decline in the numbers earning some income for wages or salaries, however, the number deriving income from business profits experienced the highest relative increase. The same was true of overseas remittances.

Mahmood, R. A. (1992) concludes that the vast majority of outward migrants were semi-skilled and unskilled. Overtime, Bangladeshi workers migrating to the region experienced significant changes in terms of their number, country of destination, and skill composition. In terms of composition of the labour force migrating to the Middle East, there has been a significant reduction in the relative's share of skilled migrants, who have given way to more low and unskilled migrants.

Although there is some agreement that increasing labour mobility would generate net overall benefits, there can also be redistribution effects and (short-term) costs. These will ultimately depend on the characteristics of migrants and labour market conditions in both sending and receiving countries (Skeldon, 2003). For instance, workers in receiving countries fear that increased competition from unskilled migrant workers may lead to lower wages or even unemployment.

The unskilled and semi-skilled workers have a high rate of turnover as their contracts are for short periods of employment and work, usually not more than two years at a time. Those completing their contracts must return home, although a large proportion of them manage to come back with new contracts which are not available before a gap of one year. This has facilitated the proliferation of recruitment and placement agencies, sometimes colluding with the prospective employers and exploiting illiterate job seekers. 8 The various forms of exploitation range from withholding of the passports; refusal of promised employment, wages, and over-time wages; undue deduction of permit fee from wages; unsuitable transport; inadequate medical facilities; denial of legal rights for redressal of complaints; use of migrants as carriers of smuggled goods; victimisation and harassment of women recruits in household jobs like maids, cooks, governesses etc (Overseas Indian, 2006, various issues).

\section{Objectives of the Study}

The key objective of this paper is to find the skill and general characteristics of Bangladeshi migrant workers. The specific objectives are:

- To enumerate the general characteristics of migrants worker.

- $\quad$ To measure the level of skill of Bangladeshi migrants.

- To analyze the level of earnings with the level of skill.

- To make some relevant recommendations for policy 
makers and potentials regarding skill development of migrants.

\section{Methodology}

This research focused on both quantitative and qualitative analysis. Both primary and secondary sources of data were used for this research purposes. Primary data were collected from individual person who works in abroad through a structured questionnaire which focuses on both quantitative and qualitative data. Convenience method of sampling is used to collect the data from the respondents. Exactly 100 samples were collected from the different area of Manikgonj District and most of the respondents were friends, relatives, neighbors and rural people. Statistical Package for Social Science (SPSS) was used for the purpose of analysis of data. Correlation, regression, mean and frequency were calculated in accordance of the objective of the study and the nature of data.

The secondary sources of data include different books, journals, articles, dissertation; annual reports and websites of World Bank, International Organization for Migration (IOM), Bangladesh Bank, annual reports of Ministry of Expatriates' Welfare and Overseas Employment of Bangladesh, and different websites relevant to the topics.

\section{Analysis and Interpretation}

\subsection{Demographic and Socio-Economic Analysis of Respondents}

\subsubsection{Gender}

Out of the 100 samples, 94 respondents that mean $6 \%$ of the respondents are male and 6 respondents that mean $6 \%$ of the respondents are female. (Table 01)

Table 01. Demographic detail of the respondents taken as a sample.

\begin{tabular}{lllllllllll}
\hline Gender & \multicolumn{9}{l}{ Age Distribution } \\
\hline Male & Female & $18-30$ & $31-40$ & $41-50$ & $51-60$ & Illiterate & Pri-mary & SSC & HSC & Under Graduate \\
94 & 6 & 37 & 39 & 18 & 6 & 34 & 40 & 18 & 5 & 3 \\
$94 \%$ & $6 \%$ & $37 \%$ & $39 \%$ & $18 \%$ & $6 \%$ & $34 \%$ & $40 \%$ & $18 \%$ & $5 \%$ & $3 \%$ \\
\hline
\end{tabular}

Source: Field Survey, 2014

\subsubsection{Age}

$37 \%$ of the respondents are between $18-30.39 \%$ of the respondents are between $31-40.18 \%$ of the respondents are between $41-50.6 \%$ of the respondents are between $41-50.6 \%$ of the respondents are above 51-60.

\subsubsection{Education}

$34 \%$ respondents have no education that means illiterate, $40 \%$ respondents have only primary education, $18 \%$ respondents have secondary education, $5 \%$ respondents have higher secondary education and $3 \%$ respondents are under graduate.

\subsubsection{Destination of Bangladeshi Migrant Workers}

Study found that the highest $45 \%$ respondents are working in Italy and the second highest number is $10 \%$ who are working in UAE, 8\% respondents are working in South Africa,7\% respondents are working in Malaysia, 4\% respondents are working in KSA and USA, 3\% respondents are working in Egypt, Libya, Oman and UK. In Brunei, Qatar and Singapore, 2\% Bangladeshi migrants are working there from Manikgonj district. Only 1\% respondent are doing their jobs in Australia, Kuwait, Maldives, South Korea.

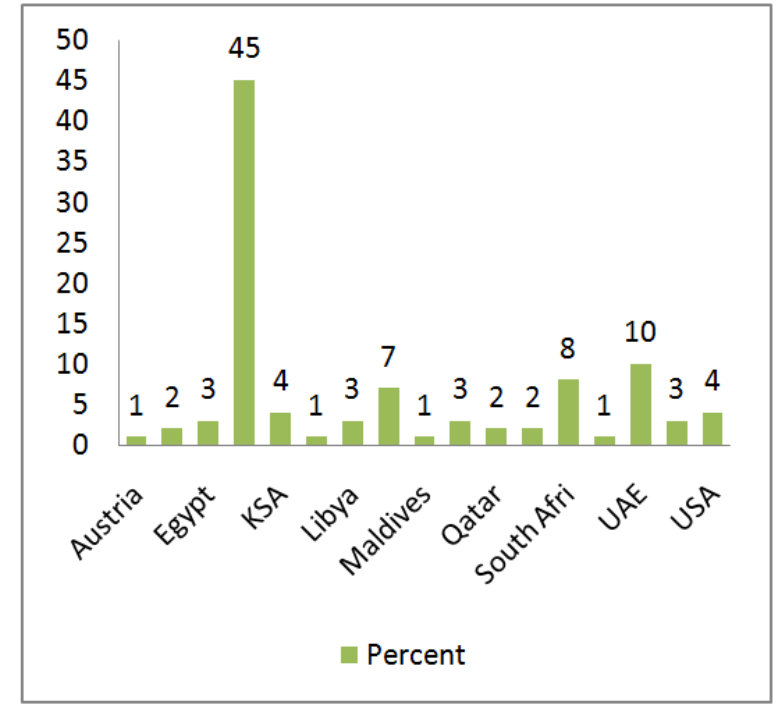

Source: Field Survey, 2014

Figure 01. Place of Destination of Migrated Workers.

\subsubsection{Previous Occupation}

$23 \%$ respondents were unemployed, $25 \%$ respondents were student, $25 \%$ respondents were farmer, $7 \%$ respondents were business man, 9\% respondents were labor and $10 \%$ respondents were service holder, and $1 \%$ respondents were home maker in Bangladesh before going abroad for working purpose. 
Table 02. Demographic and other data in detail of the respondents taken as a sample.

\begin{tabular}{|c|c|c|c|c|c|c|}
\hline \multicolumn{7}{|c|}{ Previous Occupation } \\
\hline Unemployed & Student & Agriculture & Business & labor & Service & Home maker \\
\hline 23 & 25 & 25 & 7 & 9 & 10 & 1 \\
\hline $23 \%$ & $25 \%$ & $25 \%$ & $7 \%$ & $9 \%$ & $10 \%$ & $1 \%$ \\
\hline
\end{tabular}

Table 02. Continue.

\begin{tabular}{llllll}
\hline Current Occupation & & & & \\
\hline labor & Service & Business & Driving & Unemployed & Housemaid \\
61 & 24 & 11 & 1 & 1 & 2 \\
$61 \%$ & $24 \%$ & $11 \%$ & $1 \%$ & $1 \%$ & $2 \%$ \\
\hline
\end{tabular}

Source: Field Survey, 2014

\subsubsection{Current Occupation}

At present, 63\% respondents are working as labor, 24\% respondents are engaged in service, $11 \%$ respondents are doing business, $1 \%$ respondent is serving as a driver, $2 \%$ respondents are serving as house maid, and $1 \%$ respondent is unemployed in different parts of the world.

\subsubsection{Previous Monthly Income}

Mean of the Respondent's monthly income was approximately BDT. 5000, median of the respondent's monthly income was BDT.4000; mode of the respondent's monthly income was BDT. 0, and standard deviation of the respondent's monthly income was BDT.7263 in Bangladesh.

\subsubsection{Current Monthly Income}

At present mean of the Respondent's monthly income is approximately BDT. 84,000, median of the respondent's monthly income is BDT.80000; mode of the respondent's monthly income is BDT. 100000, and standard deviation of the respondent's monthly income is BDT.64097 those Bangladeshi people have migrated from Bangladesh and have been working in different countries of the world.

\subsubsection{Change in Monthly Income}

Monthly income has been significantly increased of respondents after migration from Bangladesh to another country. Before migration monthly average income of the respondents was only BDT 5000 but after migration monthly average income of the respondents is BDT 36000 which is 7.356 times of previous monthly average.

\subsection{Analysis of Migrant Worker's Skill}

Skill is needed in every work and job; especially it is true for the migrant workers. As they work in overseas that's why they are needed some special qualities, including foreign language, relevant job skill and others. Every aspect of life--including making friends, finding a job and enjoying a successful relationship---depends greatly upon your ability to get along with others and present a positive image of yourself. Relationships with friends, significant others, bosses and employees are built upon social skills. When being considered for a job, intrapersonal skills trump education and even experience in the field according to the International Association of Administrative Professionals (IAAP). In a career setting where many people are working closely together, the ability to get along with coworkers is essential, whereas tangible skills can be taught. This skill is often judged in a short amount of time during an interview, making strong people skills crucial to securing your desired position.

\subsubsection{Level of Skill}

Skill levels of Bangladeshi migrant workers are not really satisfactory. Researchers of this paper found that only $47 \%$ of the respondents are unskilled, 7\% of the respondents have low skill, $38 \%$ of the respondents are semi-skilled and $8 \%$ of the respondents are skilled.

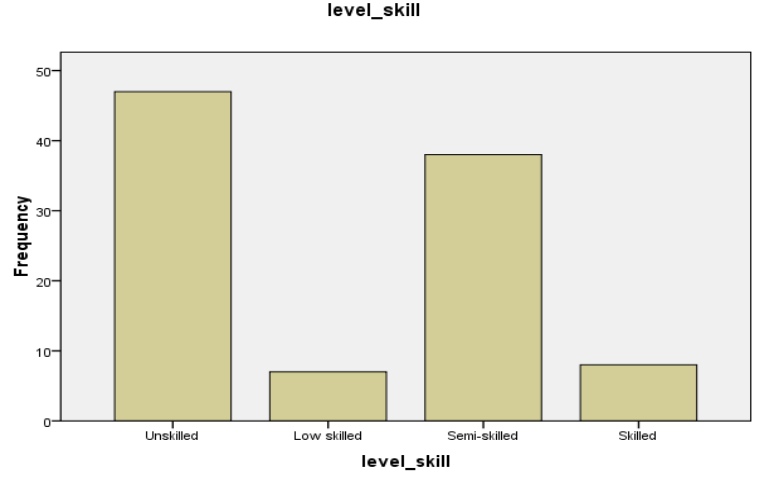

Figure 02. Level of skill of the respondents.

\subsubsection{Language Skill}

Researchers found very poor language skill of respondents in case of foreign language. Only 29\% respondents have foreign language proficiency. Although their proficiency levels are not expected level. Maximum respondents that mean $71 \%$ respondents have no foreign language proficiency.

\subsubsection{Training}

It is found from this study that only $16 \%$ respondents have taken different sorts of short term training before going abroad. Remaining $84 \%$ respondents have no training which indicates poor level of skill of Bangladeshi migrant workers.

\subsubsection{Earnings and Skill}

It is found from this study that skilled migrant workers earn much more than unskilled migrant workers. Researchers found that skilled migrant workers earn 7.36 times more than unskilled migrant workers. 


\subsection{Correlation Analysis}

The correlation between year of staying and current monthly income is positively correlated. Study found correlation between them is 0.588 which indicates moderate level of positive correlation. The correlation between current monthly earnings and monthly remittance sending is 0.844 which indicates very positive correlation. It implies that Bangladeshi migrant workers remit maximum portion of their earnings from abroad to their home country.

\section{Recommendations}

Bangladeshi migrant workers, in general are continuously facing challenges arising from low skill, skill mismatching, poor education, visa trading, high migration, and recruitment costs. Both men and women face other forms of problems, including labor market discrimination, harsh working environment, and poor working conditions. However, in order to overcome existing problems faced by Bangladeshi migrant workers and to prepare manpower as per demand of the foreign employers, researchers of this research paper, suggest following recommendations.

- Government of Bangladesh should take rigorous initiative to enhance skill of prospective migrants through Ministry of Expatriates' Welfare and Overseas Employment of Bangladesh and foreign Bangladeshi Embassy.

- Ministry of Expatriates' Welfare and Overseas Employment of Bangladesh can establish an exclusive training institute to train up prospective migrant workers continuously throughout the year.

- Ministry of Expatriates' Welfare and Overseas Employment of Bangladesh can emphasis to enhance communicative language skill as it is the common barrier of most of the migrant workers.

- Rigorous initiative should be taken and bilateral relationship should be reinforced for seeking new and potential labor market all over the world.

- Training has to be formulated in such way that matches the demand of the foreign employers.

- Government can provide necessary subsidy, sponsorship, and easy soft loan to encourage the potential migrant workers for developing relevant skill.

- Besides government other local and international organizations like NGOs, Private Commercial Banks, Financial Institutions, and International Labour Organization should come forward to co-operate prospective migrant workers from their background.

- Mass communication media can build public awareness to develop skill of prospective migrant workers.

\section{Conclusion}

It is found from this study that level of skill is positively correlated with the migrant's income. Therefore all the prospective migrants should emphasis on improving their skill. Government should take necessary steps toward generating skilled human resource in order to enhance remittance inflow which contributes country's economic growth and development. It would also be worth establishing a government system of offering low interest loans to less well-off emigrants to finance outmigration. Such a system of financing outmigration may also ensure that those emigrants availing the low interest loans would resort to formal banking channels to transfer their remittances back home. This would further augment the foreign exchange reserve, which is vital for a developing country like Bangladesh.

\section{References}

[1] A. Sibanda, "Who gets to drop out of school in South Africa? The role of individual and household attributes," African Population Studies, vol. 19, no. 1, pp. 99-117, 2004.

[2] A. T. M. N. Amin, "Economics of Rural-Urban relations reexamined in the light of growing environmental concerns," Regional Development Studies, vol. 1, pp. 27-54, 1994.

[3] B. Chukwuezi, "De-agrrianisation and Rural employment in Igboland, Southeastern Nigeria," ASC Working Paper 37, Africaka Studiecentrium, Leiden/Centre for Research and Documentation (CRD), Kano, Nigeria, 1999.

[4] Benson-Rea, M., Haworth, $\mathrm{N}$ and Rawlinson, S., "The Integration of Highly Skilled Migrants into the Labour Market: Implications for New Zealand Business", New Zealand Immigration Service, March 1998, 1-62

[5] Borooah, Vani K. \& Mangan, J., "An Analysis of Occupational Outcomes for Indigenous and Asian Employees in Australia", Economic Record, Vol. 78 (240), 2002, 31-49

[6] Chapman, Bruce J. and Iredale, Robyn R., "Immigrant Qualifications: Recognition and Relative Wage Outcomes, International Migration Review, Vol. 27 (2), 1993, 359-387.

[7] Chiswick, Barry R., "The Effects of Americanization on the Earnings of Foreign-born Men", Journal of Political Economy, Vol. 86 (5), 1978, 897-921.

[8] F. Ellis, A Livelihoods Approach to Migration and Poverty Reduction, Paper Commissioned by the Department for International Development (DFID), Overseas Development Group, University of East Anglia, 2003.

[9] G. W. Corder and D. I. Foreman, Nonparametric Statistics for Non-Statisticians, John Wiley \& Sons, Hoboken, NJ, USA, 1st edition, 2009.

[10] J. R. Harris and M. P. Todaro, "Migration, unemployment and development: a two-sector analysis," The American Economic Review, vol. 60, no. 1, pp. 126-138, 1970.

[11] J.-P. Azam and F. Gubert, "Migrant remittances and economic development in Africa: a review of evidence," in Proceedings of the AERC Plenary Session, Nairobi, Kenya, May 2005.

[12] K. P. Timalsina, Rural Urban migration and livelihood in the informal sector: a study of street vendors of Kathmandu Metropolitan City, Nepal [Philosophy Thesis in Development Studies], Department of Geography Norwegian University of Science and Technology (NTNU), 2007. 
[13] M. Z. Hossain, "Rural-Urban migration in Bangladesh: a micro level study," in Proceedings of the Brazil IUSSP Conference, August 2001.

[14] N. C. Ehirim, R. U. Onyeneke, N. M. Chidiebere-Mark, and V. C. Nnabuihe, "Effect and prospect of Rural to Urban migration on the poverty status of migrants in Abia State,

[15] N. N. Sorenson, "The development dimension of migrant remittances: toward a gendered typology," in Proceedings of the International Forum on Remittances, Washington, DC, USA, June 2004

[16] N. P. Glytsos, "The role of migrant remittances in development: evidence from Mediterranean countries," International Migration, vol. 40, no. 1, pp. 5-26, 2002.

[17] Nwajiuba, International Migration and Livelihoods in Southeastern Nigeria, Global Migration Perspectives, Geneva, Switzerland, 2005.

[18] P. C. Bhattacharya, Rural-to-Urban Migration in LDCS: A Test of Two Rival Models, Economics Division, vol. 14, School of Management, Heriot-Watt University, Edinburgh, UK, 2002.
[19] Q. M. Islam, "What about the slum dwellers," The Bangladesh Observer, Dhaka, Bangladesh, 1999.

[20] R. Afsar, Internal Migration and the Development Nexus: The Case of Bangladesh, Bangladesh Institute of Development Studies, Dhaka, Bangladesh, 2003.

[21] R. H. Adams, "Remittance and poverty in Ghana," Working Paper 3838, World Bank Policy Research, 2006. View at Publisher · View at Google Scholar

[22] R. N. C. Anyadike, Statistical Methods for the Social and Environmental Sciences, Spectrum Books, Ibadan, Nigeria, 2009.

[23] S. Pozo, "Immigrants' Remittances James Woods and Christopher O'Leary," Principles of Labor Market Information, 2007.

[24] T. Wang, A. Maruyama, and M. Kikuchi, "Rural-Urban migration and labor markets in China: a case study in a Northeastern province," The Developing Economies, vol. 38, no. 1, pp. 80-104, 2000. 